\begin{abstract}
20
Abstract

Mounier-Kuhn syndrome is a rare syndrome characterized by tracheobronchomegaly resulting from the loss or atrophy of musculo-elastic fibers within the trachea and main bronchi wall. This syndrome is more common in the third or fourth decades of life. The diagnosis can usually be made by measuring the diameters of trachea and main bronchi radiologically. A 52-year-old male patient was referred to our outpatient clinic with chronic productive cough and recurrent respiratory tract infections. We detected tracheobronchomegaly, tracheal diverticula, and bronchiectasis in the chest CT scans. This rare case is presented due to later onset than expected and very demonstrative radiological findings.
\end{abstract}

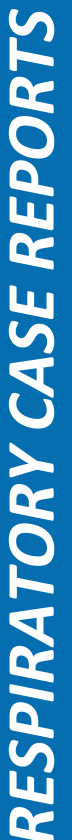

Key words: Mounier-Kuhn syndrome, tracheobronchomegaly, tracheal diverticula.
Clinic of Chest Diseases, Yedikule Chest Diseases and Chest

\title{
Mounier-Kuhn Syndrome: A Rare Cause of Recurrent Respiratory Tract Infections
}

\author{
Mounier-Kuhn Sendromu: Tekrarlayıcı Solunum Yolu Infeksiyonlarının \\ Nadir Bir Sebebi
}

Esra Ertan, Nihal Geniş, ilyas Kocabağ, Veysel Yılmaz, Mehmet Tutar

\section{Özet}

Mounier-Kuhn sendromu (MKS) trakea ve ana bronş duvarındaki muskuloelastik fibrillerin kaybolması veya atrofisi sonucu oluşan ve trakeobronkomegali ile karakterize nadir bir sendromdur. Bu sendromun tanısı daha çok hayatın 3. veya 4. dekatında konulmaktadır. Tanı genellikle trakea ve ana bronşların çaplarının radyolojik olarak ölçülmesi ile konur. Elli iki yaşında bir erkek hasta kronik prodüktif öksürük ve tekrarlayan solunum yolu infeksiyonları nedenleri ile polikliniğimize sevk edilmiş. Bilgisayarlı tomografi incelemesinde trakeobronkomegali, trakeal ve bronşiyal divertiküller ve bronşektazik alanlar saptadık. Bu nadir olguyu beklenenden daha geç başlangıçlı olması ve çok eğitici radyolojik bulgular nedeniyle sunduk.

Anahtar Sözcükler: Mounier-Kuhn sendromu, trakeobronkomegali, trakeal divertikül. Yedikule Göğüs Hastalıkları ve Göğüs Cerrahisi Hastanesi, Surgery Hospital, İstanbul, Turkey Göğüs Hastalıkları Kliniği, İstanbul

Submitted (Başvuru tarihi): 08.07.2013 Accepted (Kabul tarihi): 17.09.2013

Correspondence (iletişim): Esra Ertan, Clinic of Chest Diseases, Yedikule Chest Diseases and Chest Surgery Hospital, i̇stanbul, Turkey

e-mail: esraertan76@yahoo.com 
Anatomic abnormalities of the airways and lungs should also be considered in patients with recurrent respiratory tract infections. Mounier-Kuhn syndrome is a rare syndrome characterized by abnormal enlargement of the trachea and main bronchi. This syndrome is more common in the third or fourth decades of life. A radiological diagnosis is made by measuring the diameter of the trachea and main bronchi. The syndrome may be accompanied by bronchiectasis, diverticulum, and recurrent infections of the lower respiratory tract (1).

\section{CASE}

A 52-year-old male patient was admitted to our outpatient clinic with complaints of chronic cough and sputum. The patient had these symptoms for 16 years, particularly during the winter months, and he used antibiotics due to the increase in the amount of sputum. He had a smoking history of 20 packs/year and has been an ex-smoker for ten years. He was working in the technical service department of a lift company. The patient had hyperlipidemia and adenoidectomy operation 10 years prior. His family history was not significant.

The examination of the respiratory system revealed inspiratory crackles at the left lower field. Pulmonary function tests (PFT) indicated mild bronchial obstruction. There was no significant finding in the flow-volume loop. Enlargement of the trachea and non-homogeneously increased density in the left lower zone were detected in the chest $\mathrm{x}$-ray (Figure 1). The chest CT scan showed tracheobronchomegaly with an increase in the transverse diameter of the trachea, right and left main bronchus measured as $40 \mathrm{~mm}, 21.5 \mathrm{~mm}$, and $19 \mathrm{~mm}$, respectively. Minimal cystic bronchiectasis was detected in the right middle lobe; widely cystic bronchiectasis was seen in the lingula and the left lower lobe (Figure 2). There was also evidence of multiple diverticula involving trachea (sawtooth appearance and ondulation signs) (Figure 3).

Laboratory tests revealed increased erythrocyte sedimentation rate $(55 \mathrm{~mm} / \mathrm{h})$ and $\mathrm{C}$-reactive protein level (8 $\mathrm{mg} / \mathrm{dl}$; normal $=0-5 \mathrm{mg} / \mathrm{dl})$. He was evaluated by rheumatologist and no accompanying connective tissue disease was detected. The patient was diagnosed as primary MKS. We offered him to have respiratory physiotherapy and prescribed appropriate antibiotic for infected bronchiectasis.

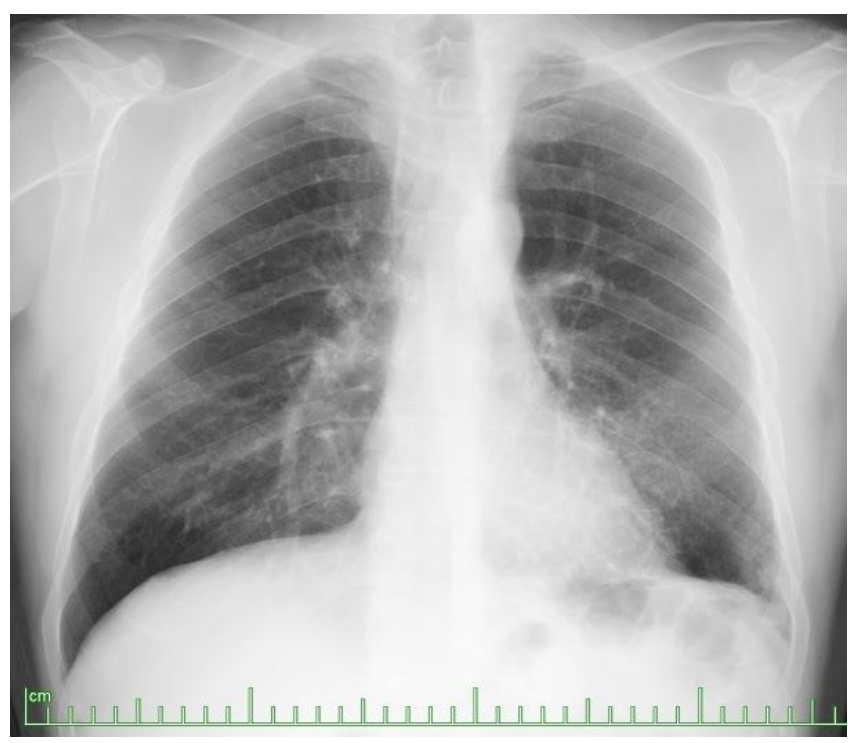

Figure 1: Chest $x$-ray of the patient

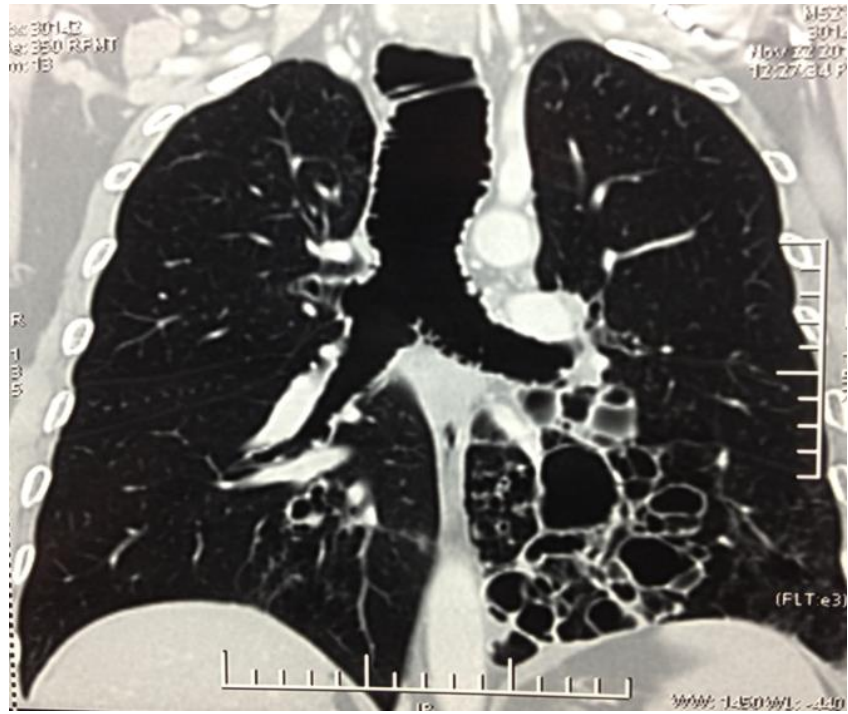

Figure 2: Dilatation of the trachea and main bronchi and cystic bronchiectasis appearance in CT

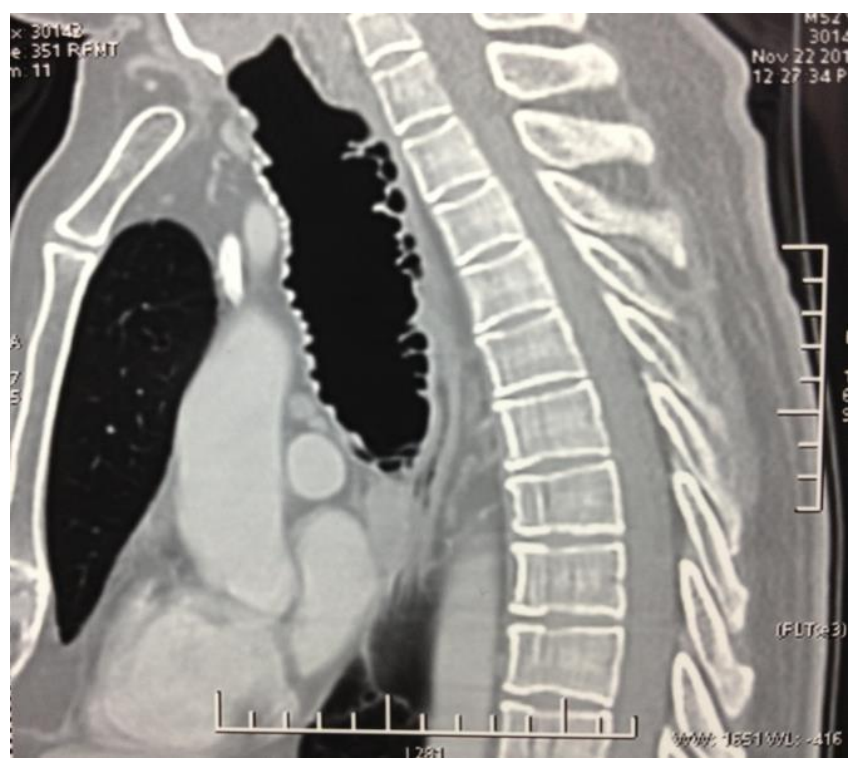

Figure 3: Sawtooth appearance and ondulation sign 


\section{DISCUSSION}

Mounier-Kuhn syndrome is a rare disease characterized by abnormal enlargement of the trachea and main bronchi. Clinical, radiological, and endoscopic findings of this syndrome were first identified by Mounier-Kuhn in 1932 (2). It is slightly more common in males and in the third or fourth decades of life. However, as in our patient, there have been reported cases detected over the age of 50 and in childhood $(3,4)$. An association has been reported between tracheobronchomegaly and Marfan syndrome, Ehler-Danlos, Kenny Caffey syndrome, connective tissue diseases, Bruton-type agammaglobulinemia, ankylosing spondylitis, ataxia-telangiectasia, Cutis Laxa, and light chain deposition disease (5). However, as in this case, most cases are sporadic and the etiology is unknown. The loss and atrophy of elastic and smooth muscle tissue of the wall of trachea and main bronchi was observed in the autopsy series (6).

Mucociliary clearance and cough mechanisms are not effective in tracheobronchomegaly. Therefore, patients usually visit physicians for recurrent respiratory tract infections, as in the current case. If there is no infection, the disease may be asymptomatic. Occasionally, the clinical picture may be accompanied by dyspnea and hemoptysis with the development of bronchiectasis. More rarely, spontaneous pneumothorax, massive hemoptysis and clubbing can be observed $(3,7,8)$.

Mounier-Kuhn syndrome is diagnosed with radiological imaging. In adults, measuring diameters for the trachea, the right main bronchus and the left main bronchus, over $30 \mathrm{~mm}, 24 \mathrm{~mm}$, and $23 \mathrm{~mm}$, respectively, are diagnostic in the chest radiograph. Trachea and main bronchi diameters for the diagnosis of Mounier-Kuhn syndrome in the CT scans are given in Table 1 (5). Tracheobronchomegaly is often accompanied by bronchiectasis and tracheal diverticula. Bronchiectasis is usually bilateral and in saccular formation (9). In the current case, bronchiectasis was cystic in formation and bilateral, but more common in the left. Tracheal diverticula radiologically elicit a sawtooth appearance and ondulation sign. The CT scan of the current patient revealed gross enlargement of the trachea and evidence of diverticula was clearly observed on the trachea and main bronchi.

Treatment of the disease involves respiratory physiotherapy to aid in the removal of secretions, and the administration of appropriate antibiotics during the attacks $(3,10)$. Previous studies reported that tracheobronchoplasty and stent application improves respiratory function and quality of life in severe cases $(11,12)$.
Table 1: Diagnostic criteria for tracheobronchomegaly with relative transverse diameters of airway at CT scan

\begin{tabular}{lccc}
\hline & $\begin{array}{c}\text { Trachea } \\
(\mathrm{mm})\end{array}$ & $\begin{array}{c}\text { Right main } \\
\text { bronchus }(\mathrm{mm})\end{array}$ & $\begin{array}{c}\text { Left main } \\
\text { bronchus }(\mathrm{mm})\end{array}$ \\
\hline Female & 21 & 19.8 & 17.4 \\
Male & $25(40)^{*}$ & $21.1(21.5)^{*}$ & $18.4(19)^{*}$ \\
* Our patient's diameters & &
\end{tabular}

As a result, assessment of the anatomy of the lungs and airways has great importance to determine the etiology of chronic productive cough and recurrent respiratory tract infections. Mounier-Kuhn syndrome should be kept in mind in the differential diagnosis of recurrent tract infections.

\section{CONFLICTS OF INTEREST}

None declared.

\section{AUTHOR CONTRIBUTIONS}

Concept - E.E., N.G., I.K., M.T., V.Y.; Planning and Design - E.E., N.G., V.Y., I.K., M.T.; Supervision - E.E., N.G., I.K., V.Y., M.T.; Funding - E.E., V.Y., N.G., I.K., M.T.; Materials - E.E., M.T., V.Y., I.K., N.G.; Data Collection and/or Processing - N.G., M.T., E.E., V.Y., I.K.; Analysis and/or Interpretation - E.E., N.G., I.K., V.Y., M.T.; Literature Review - E.E., N.G., I.K., V.Y., M.T.; Writing - E.E., N.G., I.K., V.Y., M.T.; Critical Review V.Y., IK., M.T., N.G., E.E.

\section{YAZAR KATKILARI}

Fikir - E.E., N.G., I.K., M.T., V.Y.; Tasarım ve Dizayn E.E., N.G., V.Y., I.K., M.T.; Denetleme - E.E., N.G., I.K., V.Y., M.T.; Kaynaklar - E.E., V.Y., N.G., I.K., M.T.; Malzemeler - E.E., M.T., V.Y., I.K., N.G.; Veri Toplama ve/veya İşleme - N.G., M.T., E.E., V.Y., I.K.; Analiz ve/veya Yorum - E.E., N.G., I.K., V.Y., M.T.; Literatür Taraması - E.E., N.G., I.K., V.Y., M.T.; Yazıyı Yazan - E.E., N.G., I.K., V.Y., M.T.; Eleştirel İnceleme - V.Y., IK., M.T., N.G., E.E.

\section{REFERENCES}

1. Lazzarini-de-Oliveira LC, Costa de Barros Franco CA, Gomes de Salles CL, de Oliveira AC Jr. A 38-year-old man with tracheomegaly, tracheal diverticulosis, and bronchiectasis. Chest 2001; 120:1018-20. [CrossRef]

2. Mounier-Kuhn P. Dilatation de la trachee: constatations radiographiques et bronchoscopiques. Tracheal dilata- 
tion: radiography and bronchoscopy findings. Lyon Med 1932; 150:106-9.

3. Woodring JH, Howard RS 2nd, Rehm SR. Congenital tracheobronchomegaly (Mounier-Kuhn syndrome): a report of 10 cases and review of the literature. J Thorac Imaging 1991; 6:1-10. [CrossRef]

4. Celik B, Bilgin S, Yuksel C. Mounier-Kuhn syndrome: a rare cause of bronchial dilation. Tex Heart Inst J 2011 ; 38:194-6

5. Menon B, Aggarwal B, lqbal A. Mounier-Kuhn syndrome: report of 8 cases of tracheobronchomegaly with associated complications. South Med J 2008; 101:83-7. [CrossRef]

6. Spencer $\mathrm{H}$. Congenital abnormalities of the lung: Congenital tracheobronchomegaly. In: Spencer $\mathrm{H}$, ed. Pathology of the lung. 4th ed. Oxford, UK: Pergamon Press; 1985:129-30.

7. Haro M, Vizcaya M, Jiménez López J, Núñez A, Loeches $N$, Mansilla F. Tracheobronchomegaly: an exceptional predisposing factor for pulmonary aspergillomas and massive hemoptysis. Arch Bronconeumol 2000; 36:103. 5.
8. Ciftci B, Yilmaz A, Erdoğan Y, Biber C, Turay UY, Ergun P ve ark. Mounier-Kuhn sendromu: olgu sunumu ve literatürün gözden geçirilmesi. Solunum Hastalıkları 2007; 18:79-83.

9. Bateson EM, Woo-Ming M. Tracheobronchomegaly. Clin Radiol 1973; 24:354-8. [CrossRef]

10. Jaiswal AK, Munjal S, Singla R, Jain V, Behera D. A 46year-old man with tracheomegaly, tracheal diverticulosis, and bronchiectasis: Mounier-Kuhn syndrome. Lung India 2012; 29:176-8. [CrossRef]

11. Odell DD, Shah A, Gangadharan SP, Majid A, Michaud $G$, Herth $F$, et al. Airway stenting and tracheobronchoplasty improve respiratory symptoms in Mounier-Kuhn syndrome. Chest 2011; 140:867-73. [CrossRef]

12. Dalar L, Eryüksel E, Koşar F, Karasulu AL, Urer N, Sökücü SN, at al. Central airway obstruction due to malignant fibrous histiocytoma metastasis in a case with Mounier-Kuhn syndrome. Tuberk Toraks 2012; 6:16771. [CrossRef] 